\title{
Clinical and molecular correlates of the ASPECTS in the acute phase of stroke
}

\author{
Correlação clínica e molecular com a ASPECTS na fase aguda do acidente vascular cerebral \\ Aline Mansueto MOURÃO ${ }^{1,2}$, Laélia Cristina Caseiro VICENTE², Mery Natali Silva ABREU³, \\ Romeu Vale SANT'ANNA', Fidel Castro Alves DE MEIRA', Rodrigo Menezes de Brito XAVIER', \\ Marco Túlio de Azevedo TANURE¹, Erica Leandro Marciano VIEIRA4, Leonardo Cruz DE SOUZA4, \\ Aline Silva de MIRANDA4, Milene Alvarenga RACHID4, Antônio Lucio TEIXEIRA4
}

\begin{abstract}
Background: The Alberta Stroke Program Early CT Score (ASPECTS) scale was developed for monitoring early ischemic changes on CT, being associated with clinical outcomes. The ASPECTS can also associate with peripheral biomarkers that reflect the pathophysiological response of the brain to the ischemic stroke. Objective: To investigate the association between peripheral biomarkers with the Alberta Stroke Program Early CT Score (ASPECTS) in individuals after ischemic stroke. Methods: Patients over 18 years old with acute ischemic stroke were enrolled in this study. No patient was eligible for thrombolysis. The patients were submitted to non-contrast CT in the first 24 hours of admission, being the Alberta Stroke Program Early CT Score and clinical and molecular evaluations applied on the same day. The National Institutes of Health Stroke Scale (NIHSS), modified Rankin scale and the Mini-Mental State Examination for clinical evaluation were also applied to all subjects. Plasma levels of BDNF, VCAM-1, VEGF, IL-1 $\beta$, sTNFRs and adiponectin were determined by ELISA. Results: Worse neurological impairment (NIHSS), cognitive (MEEM) and functional (Rankin) performance was observed in the group with changes in the NCTT. Patients with NCTT changes also exhibited higher levels of IL-1 $\beta$ and adiponectin. In the linear multivariate regression, an adjusted R coefficient of 0.515 was found, indicating adiponectin and NIHSS as independent predictors of ASPECTS. Conclusion: Plasma levels of adiponectin are associated with the ASPECTS scores.
\end{abstract}

Keywords: Brain Ischemia; Neurology; Biomarkers; Neurologic Examination; Prognosis.

\section{RESUMO}

Introdução: A Alberta Stroke Early Score (ASPECTS) foi desenvolvida para monitorização de alterações isquêmicas precoces na tomografia computadorizada de crânio, estando associada a desfechos clínicos. A ASPECTS também pode se associar aos biomarcadores periféricos que refletem a resposta fisiopatológica do cérebro ao AVC isquêmico. Objetivo: Investigar à associação entre os parâmetros periféricos com a Alberta Stroke Early Score (ASPECTS) em indivíduos após acidente vascular cerebral isquêmico. Métodos: Pacientes acima de 18 anos com AVC isquêmico agudo foram incluídos neste estudo. Nenhum paciente foi elegível para trombólise. Os pacientes foram submetidos à tomografia computadorizada sem contraste nas primeiras 24 horas da admissão, a ASPECTS e as avaliações clínicas e moleculares aplicadas no mesmo dia. O National Institutes of Health Stroke Scale (NIHSS), a escala de Rankin modificada e o Mini Exame do Estado Mental para avaliação clínica também foram aplicados a todos os indivíduos. Os níveis plasmáticos de BDNF, VCAM-1, VEGF, IL-1 3 , sTNFRs e adiponectina foram determinados por ELISA. Resultados: Pior desempenho neurológico (NIHSS), cognitivo (MEEM) e funcional (Rankin) foram observados no grupo com alterações na ASPECTS. Pacientes com alterações na ASPECTS também exibiram níveis mais altos de IL-1 $\beta$ e adiponectina. Na regressão multivariada linear, foi encontrado um coeficiente R ajustado de 0,515, indicando adiponectina e NIHSS como preditores independentes para a ASPECTS. Conclusão: Os níveis plasmáticos de adiponectina estão associados aos escores da ASPECTS.

Palavras-chave: Isquemia Encefálica; Neurologia; Biomarcadores; Exame Neurológico; Prognóstico.

\footnotetext{
${ }^{1}$ Universidade Federal de Minas Gerais, Hospital Risoleta Tolentino Neves, Unidade de Acidente Vascular Cerebral, Belo Horizonte MG, Brazil.

${ }^{2}$ Universidade Federal de Minas Gerais, Faculdade de Medicina, Departamento de Fonoaudiologia, Belo Horizonte MG, Brazil.

${ }^{3}$ Universidade Federal de Minas Gerais, Departamento de Enfermagem Aplicada, Belo Horizonte MG, Brazil.

${ }^{4}$ Universidade Federal de Minas Gerais, Faculdade de Medicina, Laboratório Interdisciplinar de Investigação Médica, Belo Horizonte MG, Brazil.

Aline Mansueto MOURÃO (iD) https://orcid.org/0000-0001-5252-6758; Laélia Cristina Caseiro VICENTE (iD https://orcid.org/0000-0003-2215-5604; Mery Natali Silva ABREU (D) https://orcid.org/0000-0002-6691-3537; Romeu Vale SANT'ANNA (D) https://orcid.org/0000-0003-1796-5979;

Fidel Castro Alves DE MEIRA (iD) https://orcid.org/0000-0002-3840-898X; Rodrigo Menezes de Brito XAVIER (ID) https://orcid.org/0000-0003-2781-893X;

Marco Túlio de Azevedo TANURE (iD https://orcid.org/0000-0001-6469-1347; Erica Leandro Marciano VIEIRA (iD https://orcid.org/0000-0002-4147-5614;

Leonardo Cruz DE SOUZA (D) https://orcid.org/0000-0001-5027-9722; Aline Silva de MIRANDA (iD) https://orcid.org/0000-0002-4417-2483;

Milene Alvarenga RACHID (ID) https://orcid.org/0000-0002-3142-6552; Antônio Lucio TEIXEIRA (D) https://orcid.org/0000-0002-9621-5422

Correspondence: Aline Mansueto Mourão; E-mail: alinemmourao@gmail.com.br

Support: This study was funded by Fundação de Amparo à Pesquisa do Estado de Minas Gerais — FAPEMIG [grant number APQ-03539-13].

Conflict of Interest: There is no conflict of interest to declare.
}

Received on August 20, 2019; Received in its final form on November 1, 2019; Accepted on December 8, 2019. 
The non-contrast computed tomography of the skull (NCCT) is the diagnostic procedure of choice for the evaluation of stroke in emergency situations. It is fast and widely available, not requiring contrast ${ }^{1,2,3}$. Moreover, NCCT is highly sensitive for intracerebral hemorrhage detection, being the most used neuroimaging method for the selection of patients with ischemic stroke for thrombolysis ${ }^{4,5,6}$.

The Alberta Stroke Program Early CT Score (ASPECTS) scale was developed for detection and quantification of early ischemic changes on $\mathrm{NCCT}^{6,7}$. This instrument contributes to stratify the risk for hemorrhagic transformation of brain ischemic areas and assist in the interpretation of the criteria for thrombolysis ${ }^{6,7,8}$. The ASPECTS is especially useful to quantify ischemic signs in the territory of the middle cerebral artery, the most often affected area in stroke ${ }^{7,8}$. Importantly, the ASPECTS has been consistently associated to clinical outcomes ${ }^{6}$.

The acute ischemic region is highly dynamic. Neuronal cells can lose their function in a few minutes, leading to neurological signs and impairment $t^{9,10,11,12,13,14,15,16,17}$. Post-stroke inflammation may contribute to both ischemic injury extension and brain recovery 4,9,16,17,18,19,20,21. Blood-based biomarkers, including inflammation-related markers, have been associated to the volume of cerebral infarction and severity of neurological deficits $3,4,10,12,17$. A growing literature on stroke biomarkers has emerged, but no blood-based predictive biomarker was validated in the acute phase of stroke ${ }^{17,22}$.

Considering the predictive value of the $\mathrm{NCCT}^{6}$, this exploratory study aimed at evaluating whether blood-based or peripheral biomarkers are associated to the ASPECTS. Our hypothesis is that ASPECTS is associated to peripheral biomarkers that reflect the pathophysiological response of the brain to the ischemic stroke.

\section{METHODS}

\section{Patients}

Patients over 18 years old with the diagnosis of ischemic stroke (ictus time $<24$ hours) admitted at the Stroke Unit, Risoleta Tolentino Neves Hospital (Belo Horizonte City, Minas Gerais State) from January to June 2015, were eligible for the study. No patient was eligible for thrombolysis due to the prolonged ictus time ( $>4$ hours) at hospital arrival.

Exclusion criteria were individuals diagnosed with ischemic stroke with hemorrhagic transformation; transient ischemic attack; diagnosis of other neurological and/or major psychiatric disorders; clinical instability. Patients with significant reduction of consciousness level according to the Glasgow Coma Scale (value less than 15); aphasia according to the National Institutes of Health Stroke Scale; delirium according to the Confusion Assessment Method were also excluded.

The study was conducted in accordance with Resolution 466/2012. The project was evaluated and approved by the Research Ethics Committee of the Federal University of Minas Gerais, Project: CAAE - 32809514.4.4.0000.5149

\section{Assessment tools}

\section{Clinical parameters}

Clinical and socio-demographic data were extracted from the medical records and/or obtained after interview with patients. Age, risk factors and pathophysiological mechanisms with the Trial of Org 10172 in Acute Stroke Treatment $(\mathrm{TOAST})^{23}$ and Oxfordshire Community Stroke Project $(\mathrm{OCSP})^{24}$ were recorded.

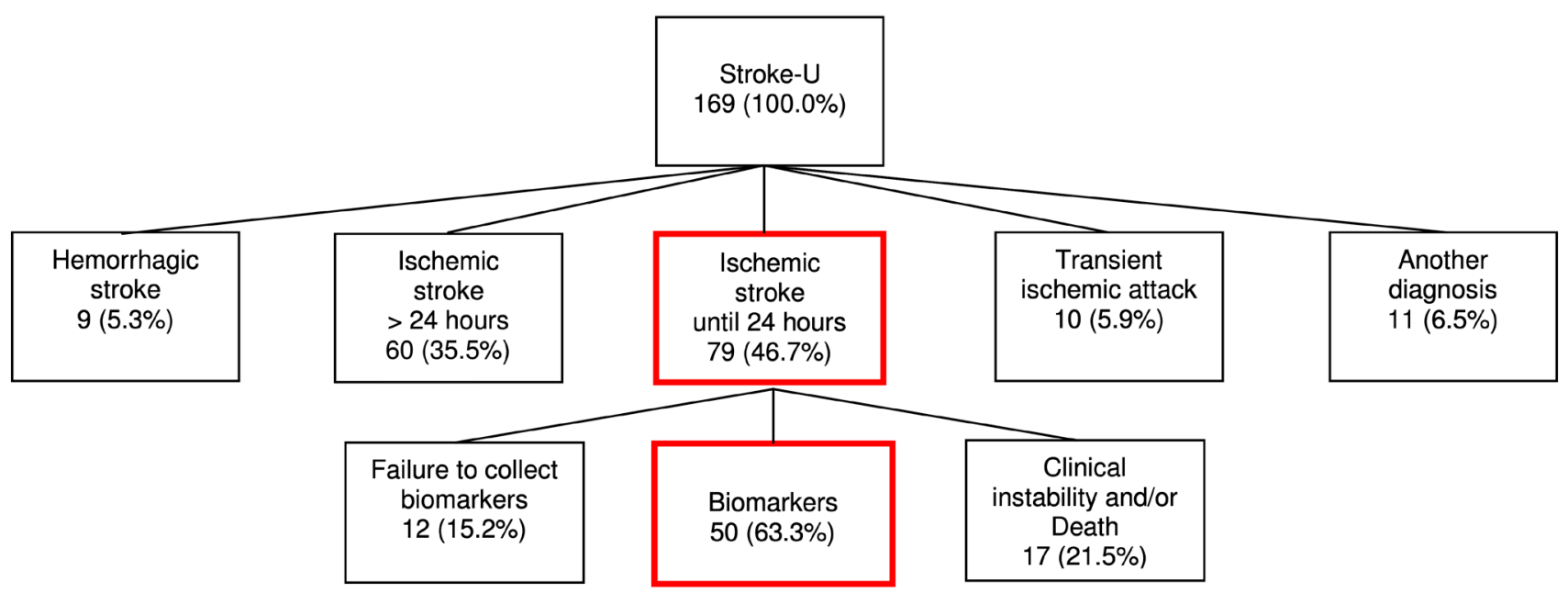

Figure 1. Number of patients included in the present study from January to July 2015. 
The clinical assessment took place within the first 24 hours of ictus. The National Institutes of Health Stroke Scale (NIHSS) ${ }^{25}$ was used to quantify the neurological impairment. The modified Rankin scale was used to quantify the degree of disability and dependence in daily life activities (DLA) ${ }^{25}$ and the Mini-Mental State Examination (MMSE) to assess cognitive functioning ${ }^{26}$.

The NIHSS and Rankin were applied through clinical examination/interview by two trained clinicians with good inter-observer agreement (kappa=0.850). The other clinical tools were applied by a single researcher.

\section{Neuroimaging}

All patients were submitted to the NCCT in the first 24 hours of admission. The ASPECTS ${ }^{6}$ was applied to quantify the extension of brain tissue changes in the anterior circulation. According to the ASPECTS, the territory of the middle cerebral artery is subdivided into 10 standard regions evaluated in two cuts of the NCCT: at the height of the thalamus and basal ganglia, and just above the basal ganglia. A normal NCCT has ASPECTS score equal to 10. A zero value indicates diffuse ischemia in the whole territory of the middle cerebral artery. Patients with value lesser than or equal to 7 have a higher risk of hemorrhagic transformation and worse prognosis ${ }^{6,7,8}$. The ASPECTS was applied by an experienced stroke neurologist.

\section{Measurement of inflammatory parameters}

Ten milliliters of blood were drawn with venipuncture in vacuum tubes containing EDTA (Vacuplast, Huangyan, China) within the first 24 hours of admission. The blood was processed within 2 hours of sampling. These samples were then centrifuged at $3000 \mathrm{~g}$ for $10 \mathrm{~min}, 4^{\circ} \mathrm{C}$, twice. The plasma was collected and stored at $-70^{\circ} \mathrm{C}$ until assayed.

Plasma levels of IL-1 $\beta$, sTNFR-1, sTNFR-2, VCAM-1, VEGF, Adiponectin and BDNF were measured by EnzymeLinked Immunosorbent Assay (ELISA) according to the procedures supplied by the manufacturer (DuoSet, R\&D Systems, Minneapolis, MN, USA). Concentrations were obtained against a standard curve calibrated with known amounts of protein and expressed as pg/mL, except for VCAM-1 levels, which were expressed as ng/mL. All samples were assayed in duplicate and in a single assay to avoid inter-assay variation. The intra-assay variation was under $3 \%$. The detection limits were $3 \mathrm{ng} / \mathrm{mL}$ for VCAM-1, $5 \mathrm{pg} / \mathrm{mL}$ for adiponectin and BDNF, $3 \mathrm{pg} / \mathrm{mL}$ for IL-1 $\beta, 9 \mathrm{pg} / \mathrm{mL}$ for VEGF and $10 \mathrm{pg} / \mathrm{mL}$ for STNFR1 and STNFR2.

\section{Statistical analysis}

The categorical variables were described according to frequencies and percentages. For the statistical analysis, the SPSS v.20.0 program was used. A bilateral p-value lesser than 0.05 was adopted as statistical significance level for all tests. The variables were evaluated for normality with the Shapiro-Wilk test. Given that most variables did not show a normal distribution, non-parametric tests were used. For comparisons between different

Table 1. Socio-demographic and Clinical Characteristics of Patients with Ischemic Stroke in the Acute Phase.

\begin{tabular}{lcc}
\hline & \multicolumn{2}{c}{ Patients $(\mathrm{n}=50)$} \\
\cline { 2 - 3 } Variables & $\mathrm{n}$ & $\begin{array}{c}\text { Proportion } \\
(\%)\end{array}$ \\
\hline Gender & & \\
Male & 28 & 56 \\
Female & 22 & 44 \\
Age (years) & & \\
Mean \pm DPM & \multicolumn{2}{c}{$65.5 \pm 11.7$} \\
Median (range) & \multicolumn{2}{c}{$64.5(37-93)$}
\end{tabular}

Comorbidities

\begin{tabular}{|c|c|c|}
\hline Hypertension & 36 & 72 \\
\hline Tobacco Smoking** & 16 & 32 \\
\hline Diabetes Mellitus & 14 & 28 \\
\hline Sedentary lifestyle & 11 & 22 \\
\hline Alcoholism* & 8 & 16 \\
\hline Ex-Smoker** & 4 & 8 \\
\hline Obesity & 4 & 8 \\
\hline Arrhythmia & 4 & 8 \\
\hline Atrial fibrillation & 2 & 8 \\
\hline Chagas disease & 2 & 4 \\
\hline Ex-Alcoholic* & 2 & 4 \\
\hline revious history of stroke & 25 & 50 \\
\hline $\begin{array}{l}\text { igns of old ischemia in the brain } \\
\text { omputed tomography (TCC) }\end{array}$ & 17 & 34 \\
\hline \multicolumn{3}{|l|}{ CPS } \\
\hline Partial anterior circulation & 31 & 62 \\
\hline Lacunar & 16 & 32 \\
\hline Posterior circulation & 3 & 6 \\
\hline Total anterior circulation & 0 & 0 \\
\hline \multicolumn{3}{|l|}{ OAST } \\
\hline Occlusion of small arteries & 25 & 50 \\
\hline Undefined mechanism & 10 & 20 \\
\hline Atherosclerosis of large arteries & 8 & 16 \\
\hline Cardioembolic & 6 & 12 \\
\hline Other etiologies & 1 & 2 \\
\hline \multicolumn{3}{|l|}{ lospital stay (days) } \\
\hline Mean£DPM & \multicolumn{2}{|c|}{$10.3 \pm 6.8$} \\
\hline Median (range) & \multicolumn{2}{|c|}{$9.0(4-30)$} \\
\hline
\end{tabular}

$\mathrm{n}$ : number of patients; DPM: Average Standard Deviation; TCC: Brain Computed Tomography; OCSP: Oxfordshire Community Stroke Project; ECG: Glasgow Coma Scale; TOAST: Trial of Org 10172 in Acute Stroke Treatment. *Criterion for alcoholism: consume any type and/or amount of alcohol. Ex-alcoholic: has stopped to consume any type and/or amount of alcohol for more than 1 year. ${ }^{*}$ Criterion for tobacco smoking: consume any type and/or amount of tobacco. Ex-smoker: stopped to consume any type and/or amount of tobacco for more than 1 year. 
groups, the Mann-Whitney test was applied. For correlations between the ASPECTS and independent variables, the Spearman test was used. Finally, the linear regression model was adjusted with the Backward method considering a p-value lesser than 0.20 to enter the covariates in the model. The adjustment of the model was assessed by means of adjusted $\mathrm{R}^{2}$ statistics.

\section{RESULTS}

Fifty patients participated in the present study (Figure 1). Demographic and clinical data are shown in Table 1. The average age of patients was 65.5 , and $56.0 \%$ were male. Among the clinical comorbidities, hypertension was the most common, present in $72 \%$ of them.

Table 2. Comparison between Alberta Stroke Program Early CT Score and Socio-demographic and Clinical Variables of Patients with Ischemic Stroke in the Acute Phase.

\begin{tabular}{|c|c|c|c|c|c|}
\hline \multirow{3}{*}{ Variables } & \multirow{2}{*}{\multicolumn{2}{|c|}{$\begin{array}{c}\text { ASPECTS }<10 \\
(n=26)\end{array}$}} & \multirow{2}{*}{\multicolumn{2}{|c|}{$\begin{array}{c}\text { ASPECTS }=10 \\
(n=24)\end{array}$}} & \multirow{3}{*}{$p$-value* } \\
\hline & & & & & \\
\hline & $\mathrm{n}$ & Proportion (\%) & $\mathrm{n}$ & Proportion (\%) & \\
\hline \multicolumn{6}{|l|}{ Gender } \\
\hline Male & 14 & (53.8) & 14 & (58.3) & \multirow{2}{*}{$0.783 * \star$} \\
\hline Female & 12 & $(46.2)$ & 10 & $(41.7)$ & \\
\hline \multicolumn{6}{|l|}{ Age (years) } \\
\hline Mean $\pm D P M$ & \multicolumn{2}{|c|}{$67.1 \pm 12$} & \multicolumn{2}{|c|}{$63.8 \pm 11.4$} & 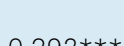 \\
\hline Median (range) & \multicolumn{2}{|c|}{$66(43-93)$} & \multicolumn{2}{|c|}{$63(37-82)$} & $0.392 \pi x$ \\
\hline
\end{tabular}

Comorbidities

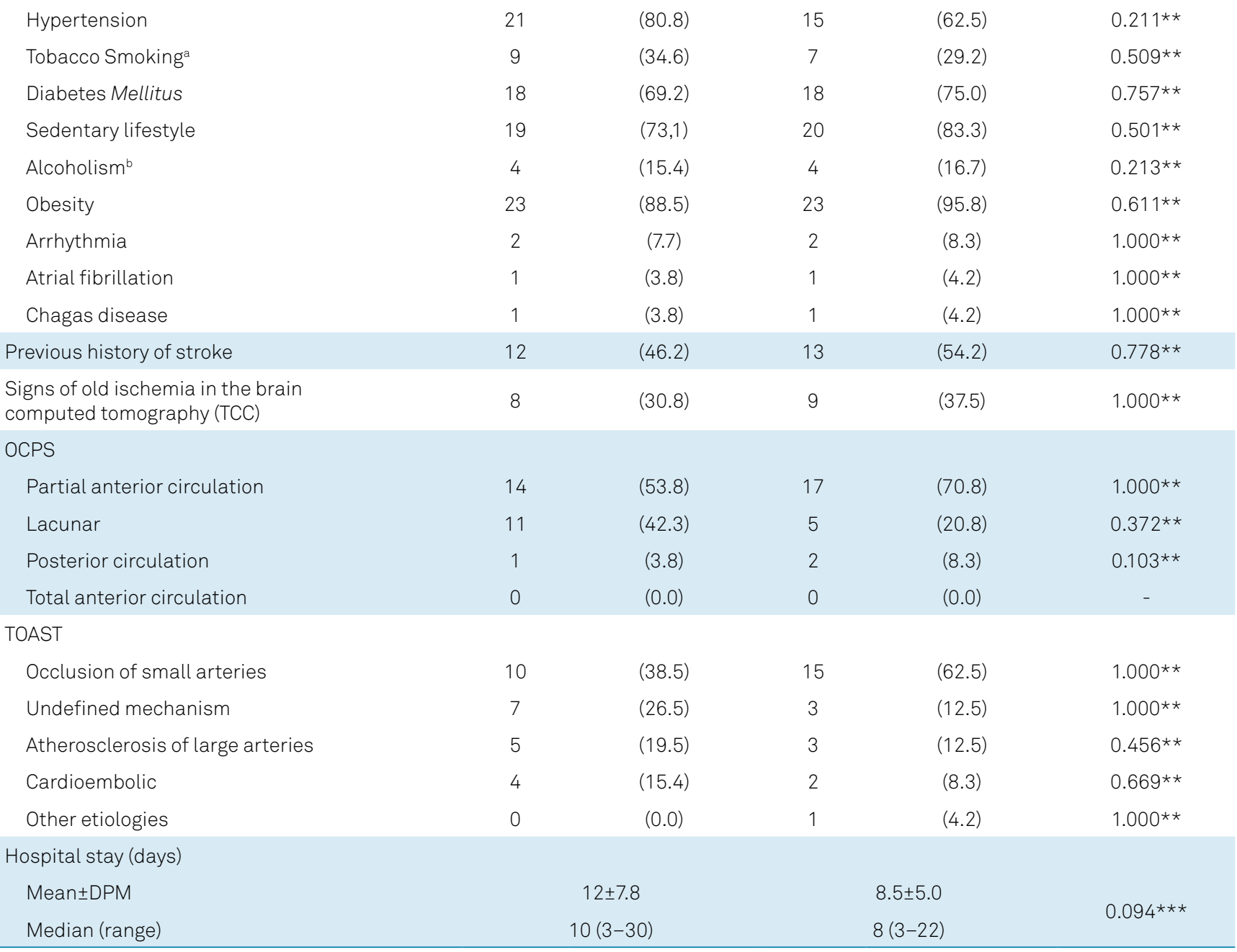

TCC: Brain Computed Tomography; OCSP: Oxfordshire Community Stroke Project; ECG: Glasgow Coma Scale;TOAST:Trial of Org 10172 in Acute Stroke Treatment; ${ }^{a}$ Criterion for tobacco smoking: consume any type and/or amount of tobacco; ${ }^{b}$ Criterion for alcoholism: consume any type and/or amount of alcohol. *Statistical test; ${ }^{*}$ Fisher exact test; $* \star \star$ Mann-Whitney test. 
The most common pathophysiological mechanism was the occlusion of small arteries (50\%).

There was no statistically significant difference in the socio-demographic and clinical characteristics between groups of patients with and without change in the NCTT (Table 2). Worse neurological impairment (NIHSS), cognitive (MEEM) and functional (Rankin) performance was observed in the group with changes in the NCTT (Table 3). Patients with NCTT changes also exhibited higher levels of IL-1 $\beta$ and adiponectin (Table 3).

There was a significant negative correlation between ASPECTS and NIHSS, mRankin and the levels of IL-1 $\beta$ and adiponectin. Conversely, there was a positive correlation between ASPECTS and BDNF levels (Table 4).

In the linear multivariate regression, an adjusted $\mathrm{R}$ coefficient of 0.515 was found, indicating adiponectin and NIHSS as independent predictors of ASPECTS (Table 5).

Table 3. Comparison Between Alberta Stroke Program Early CT Score and Molecular and Clinical Variables of Patients with Ischemic Stroke During Hospital Admission.

\begin{tabular}{|c|c|c|c|c|}
\hline \multirow{2}{*}{ Variables } & ASPECTS $<10$ & ASPECTS $=10$ & \multirow{2}{*}{ Z } & \multirow{2}{*}{$p$-value* } \\
\hline & $(n=26)$ & $(n=24)$ & & \\
\hline \multicolumn{5}{|l|}{ Molecular } \\
\hline \multicolumn{5}{|l|}{$\mathrm{BDNF}-\mathrm{pg} / \mathrm{mL}$} \\
\hline Mean $\pm D P M$ & $9052.4 \pm 2289.4$ & $10449.0 \pm 2861.9$ & \multirow{2}{*}{-1.709} & \multirow{2}{*}{0.087} \\
\hline Median (min-max) & $9081.5(3975-14531)$ & $10679.5(4101-14527)$ & & \\
\hline \multicolumn{5}{|l|}{ VCAM-1 - pg/mL } \\
\hline Mean $\pm D P M$ & $469342.3 \pm 264710$ & $595294 \pm 643039.3$ & \multirow{2}{*}{-0.738} & \multirow{2}{*}{0.461} \\
\hline Median (min-max) & $382530(173060-1282480)$ & $484260(158400-3482720)$ & & \\
\hline \multicolumn{5}{|l|}{ VEGF - pg/mL } \\
\hline Mean $\pm D P M$ & $359.4 \pm 267.4$ & $391.2 \pm 274.6$ & \multirow{2}{*}{-0.330} & \multirow{2}{*}{0.741} \\
\hline Median (min-max) & $286.5(20-1115)$ & $291.6(63-1088)$ & & \\
\hline \multicolumn{5}{|l|}{ IL-1beta - pg/mL } \\
\hline Mean£DPM & $10.0 \pm 15.5$ & $3.5 \pm 7.0$ & \multirow{2}{*}{-2.185} & \multirow{2}{*}{$0.029 * *$} \\
\hline Median (min-max) & $2.5(0-56)$ & $0.5(0-27)$ & & \\
\hline \multicolumn{5}{|l|}{ Adiponectin - pg/mL } \\
\hline 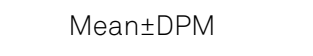 & $664269.2 \pm 375062.5$ & $430270.8 \pm 229851.2$ & \multirow{2}{*}{-2.214} & \multirow{2}{*}{$0.027 * \star$} \\
\hline Median (min-max) & $577450(146700-1662900)$ & $453650(78100-934000)$ & & \\
\hline \multicolumn{5}{|l|}{ sTNFR1 - pg/mL } \\
\hline Mean $\pm D P M$ & $1798.0 \pm 901.0$ & $2397.6 \pm 1455.0$ & \multirow{2}{*}{-1.660} & \multirow{2}{*}{0.097} \\
\hline Median (min-max) & $1488(591-4320)$ & 2096 (690-7361) & & \\
\hline \multicolumn{5}{|l|}{ sTNFRII - pg/mL } \\
\hline Mean£DPM & $3450 \pm 1241.0$ & $4017.7 \pm 1818.0$ & \multirow{2}{*}{-1.068} & \multirow{2}{*}{0.285} \\
\hline Median (min-max) & $3586(1358-5805)$ & $3957.5(1527-7716)$ & & \\
\hline \multicolumn{5}{|l|}{ Clinics } \\
\hline \multicolumn{5}{|l|}{ MEEM } \\
\hline Mean $\pm D P M$ & $16.8 \pm 6.0$ & $20.5 \pm 5.8$ & \multirow{2}{*}{-2.000} & \multirow{2}{*}{$0.045^{\star \star}$} \\
\hline Median (min-max) & $16(0-30)$ & $21(12-29)$ & & \\
\hline \multicolumn{5}{|l|}{ NIHSS } \\
\hline Mean£DPM & $10.5 \pm 6.4$ & $5.8 \pm 4.9$ & -3.292 & $0,001 * *$ \\
\hline Median (min-max) & $9.0(0-30)$ & $5.0(0-21)$ & $-3 . \angle 9 \angle$ & 0.001 \\
\hline Rankin & & & & \\
\hline Mean士DPM & $3.3 \pm 1.5$ & $2.4 \pm 1.5$ & -2.515 & $0.012 * *$ \\
\hline Median (min-max) & $4.0(0-5)$ & $3.0(0-)$ & -2.510 & $0.01 Z^{\circ}$ \\
\hline
\end{tabular}

n: number of patients; DPM: Average Standard Deviation; ASPECTS: Alberta Stroke Program Early CT Score; BDNF: Brain Derived Neurotrophic Factor; VCAM-1: Vascular Cell Adhesion Molecule-1;VEGF:Vascular Endothelial Growth Factor; IL-1 b: Interleukin-1 beta; sTNFR1: receptors of Tumor Necrosis Factors 1; sTNFRII: receptors of Tumor Necrosis Factors 2; MEEM: Mini-Mental State Examination; BAF: Frontal Assessment Battery; NIHSS: National Institutes of Health Stroke Scale; Rankin: Modified Rankin Scale; *Statistical test; **Mann-Whitney test. 


\section{DISCUSSION}

The current results showed that the ASPECTS is associated to clinical and peripheral molecular markers. This study corroborates the robust literature on the association between the extension of the stroke, as assessed by the ASPECTS, and the severity of the neurological impairment, as evaluated by the NIHSS ${ }^{6,7,8}$. Furthermore, it supports our original hypothesis that ASPECTS is associated to peripheral biomarkers, i.e., plasma levels of adiponectin, in the acute phase of stroke.

Several studies show that both the extension of the stroke, as assessed by the ASPECTS, and the severity of neurological impairment, as assessed by NIHSS in the first 24 hours, are reliable predictors of clinical outcome in the long term,

Table 4. Correlations Between Alberta Stroke Program Early CT Score with Molecular and Clinical Assessments of Patients with Ischemic Stroke During Hospital Admission.

\begin{tabular}{lcc}
\hline Variables & Rho & p-value* \\
Molecular & & \\
BDNF & 0.307 & $0.030 *$ \\
VCAM-1 & 0.110 & 0.448 \\
VEGF & 0.040 & 0.785 \\
IL-1b & -0.357 & $0.011 *$ \\
Adiponectin & -0.348 & $0.013^{*}$ \\
STNFRI & 0.229 & 0.109 \\
sTNFRII & 0.211 & 0.142 \\
Clinics & & \\
MEEM & 0.223 & 0.120 \\
NIHSS & -0.419 & $0.002 *$ \\
Rankin & -0.332 & $0.019 *$ \\
\hline
\end{tabular}

n: number of patients; DPM: Average Standard Deviation; ASPECTS: Alberta Stroke Program Early CT Score; BDNF: Brain Derived Neurotrophic Factor; VCAM-1: Vascular Cell Adhesion Molecule-1; VEGF: Vascular Endothelial Growth Factor; IL-1b: Interleukin-1 beta; sTNFR1: receptors of Tumor Necrosis Factors 1; sTNFRII: receptors of Tumor Necrosis Factors 2; MEEM: Mini-Mental State Examination; BAF: Frontal Assessment Battery; NIHSS: National Institutes of Health Stroke Scale; Rankin: Modified Rankin Scale; Statistical Test: *Spearman.

Table 5. Linear Multivariate Regression Analysis Between Alberta Stroke Program Early CT Score with Independent Variables Effectively Associated of Patients with Ischemic Stroke During Hospital Admission.

\begin{tabular}{lccc} 
Variables & Coefficient B & p-value & $\begin{array}{c}95 \% \text { confidence } \\
\text { interval }\end{array}$ \\
\hline $\begin{array}{l}\text { Molecular } \\
\text { Adiponectin }\end{array}$ & -1.504 & 0.005 & $0.000-0.000$ \\
$\begin{array}{l}\text { Clinics } \\
\text { NIHSS }\end{array}$ & -0.078 & 0.006 & $-0.132-0.023$ \\
\hline
\end{tabular}

NIHSS: National Institutes of Health Stroke Scale; Statistical test: *Linear multivariate regression analysis; Adjusted R coefficient $=0.518$. including perception of quality of life and functionality ${ }^{8,24,27}$. Actually, these are highly correlated constructs as shown here and by others ${ }^{8,28,29,30}$.

In the context of the physiological response to the brain ischemia, the inflammatory response takes place with the production and release of various pro-inflammatory cytokines $^{9,10,11}$. For instance, preclinical ${ }^{18,19,30}$ and clinical ${ }^{30,31}$ studies have shown increased production of IL1- $\beta$ in the first 24 hours after the stroke. In line with this, patients with NCTT changes compatible with larger ischemic area exhibited higher circulating levels of IL-1 $\beta$.

In the post-stroke inflammatory response, there is also the production of anti-inflammatory and neuroprotective molecules to counterbalance and control the process. For example, stroke is associated to increased expression of BDNF, one of the main neurotrophic factors in the central nervous system, by neurons, microglia and endothelial cells in animal models ${ }^{13,14,15,16}$. Increased levels of BDNF have been reported in patients with stroke as well, and its levels were associated to clinical outcomes ${ }^{21,31}$. Interestingly, BDNF correlated with ASPECTS, but it did not remain in the final multivariate model.

Adiponectin exhibits anti-atherosclerotic, anti-inflammatory, and anti-diabetic effects ${ }^{20,21,32,33,34}$. High levels of adiponectin have been shown to protect against coronary artery disease ${ }^{21,32}$. Conversely, chronic inflammation present in obesity and metabolic syndrome inhibits the synthesis of adiponectin ${ }^{20,21,32}$. In the current study, higher levels of adiponectin were observed in patients with larger ischemic lesions. This is the first study to identify the association between adiponectin and the extension of brain lesion after ischemic stroke. Besides suggesting a potential role for this molecule as a prognostic biomarker, this highlights the complexity of pro- and anti-inflammatory mechanisms involved in the physiological response of the ischemic brain.

The results must be interpreted with its limitations, that include relatively small sample size and the strict selection criteria that limit its generalizability. Half of the sample had small vessel occlusion as the probable mechanism of the stroke, whereas large vessel diseases accounted for less than $20 \%$ of the cases. Conversely, the panel of molecules assessed, comprising different mechanisms and pathways, might be regarded as a strength of the study.

\section{CONCLUSION}

Plasma levels of adiponectin are associated to the ASPECTS scores. Further studies must confirm this finding, evaluating the potential of this molecule as a prognostic biomarker after ischemic stroke. 
1. Jauch EC, SaverJL, Adams HPJR, Bruno A, Connors JJ, Demaerschalk BM, et al. Guidelines for the early management of patients with acute ischemic stroke: a guideline for healthcare professionals from the American Heart Association/American Stroke Association Stroke. Stroke. 2013 Mar;44(3):870-947. https://doi.org/10.1161/STR.0b013e318284056a

2. Copen WA, Morais LT, Wu O, Schawamm LH, Schaefer PW, González RG, et al. In acute stroke, can CT perfusion-derived cerebral blood volume maps substitute for diffusion-weighted imaging in identifying the ischemic core? PLoS One. $2015 \mathrm{Jul} ; 10(7): \mathrm{e} 0133566$. https://doi.org/10.1371/journal.pone.0133566

3. Jickling GC, Sharp FR. Blood biomarkers of ischemic stroke. Neurotherapeutics. 2011 Jul;8(3):349-60.https://doi.org/10.1007/s13311-011-0050-4

4. Whiteley W, Wardlaw J, Dennis M, Lowe G, Rumley A, Sattar N, et al. Blood biomarkers for the diagnosis of acute cerebrovascular diseases: a prospective cohort study. Cerebrovasc Dis. 2011;32(2):141-7. https://doi.org/10.1159/000328517

5. Goyal M. Poor clinical outcome despite successful arterial recanalization. What went wrong? How can we do better? Neuroradiology. 2010 May;52(5):341-3. https://doi.org/10.1007/s00234-009-0636-2

6. Barber PA, DemchukAM, Zhang J, Buchan AM. Validity and reliability of a quantitative computed tomography score in predicting outcome of hyperacute stroke before thrombolytic therapy. Lancet. 2000 May;355(9216):1670-4. https://doi.org/10.1016/s0140-6736(00)02237-6

7. Puetz V, Dzialowski I, Hill MD, Demchuk AM. The Alberta Stroke Program Early CT Score in clinical practice: what have we learned? Int J Stroke. 2009 Oct;4(5):354-64. https://doi.org/10.1111/j.1747-4949.2009.00337.x

8. Padroni M, Bernardoni A, Tamborino C, Roversi G, Borrelli M, Saletti $A$, et al. Cerebral blood volume ASPECTS is the best predictor of clinical outcome in acute ischemic stroke: a retrospective, combined semi-quantitative and quantitative assessment. PLoS One. 2016 Jan;11(1):e0147910. https://doi.org/10.1371/journal.pone.0147910

9. Doll DN, Barr TL, Simpkins JW. Cytokines: their role in stroke and potential use as biomarkers and therapeutic targets. Aging Dis. 2014 Oct;5(5):294-306. https://doi.org/10.14336/AD.2014.0500294

10. Brouns R, De Deyn PP. The complexity of neurobiological processes in acute ischemic stroke. Clin Neurol Neurosurg. 2009 Jul;111(6):483-95. https://doi.org/10.1016/j.clineuro.2009.04.001

11. Kunz A, Dirnagl U, Mergenthaler P.Acute pathophysiological processes after ischaemic and traumatic brain injury. Best Pract Res Clin Anaesthesiol. 2010 Dec;24(4):495-509. https://doi.org/10.1016/j.bpa.2010.10.001

12. Teixeira AL, Barbosa IG, Diniz BS, Kummer A. Circulating levels of brain-derived neurotrophic factor: correlation with mood, cognition and motor function. Biomark Med. 2010 Dec;4(6):871-87.https://doi.org/10.2217/bmm.10.111

13. Béjot Y, Prigent-Tessier A, Cachia C, Giroud M, Mossiat C, Bertrand $\mathrm{N}$, et al. Time dependent contribution of non neuronal cells to BDNF production after ischemic stroke in rats. Neurochem Int. 2011 Jan;58(1):102-11. https://doi.org/10.1016/j.neuint.2010.10.019

14. Béjot Y, Mossiat C, Giroud M, Prigent-Tessier A, Marie C. Circulating and Brain BDNF Levels in Stroke Rats. Relevance to Clinical Studies Plos One. 2011 Dec;6(12):e29405. https://doi.org/10.1371/journal.pone.0029405

15. Chen A, Xiong LJ, Tong Y, Mao M. The neuroprotective roles of BDNF in hypoxic ischemic brain injury. Biomed Rep. 2013 Mar;1(2):167-76. https://doi.org/10.3892/br.2012.48

16. Di Lazzaro V, Profice P, Pilato F, Dileone M, Florio L, Tonali PA, et al. BDNF plasma levels in acute stroke. Neurosci Lett. 2007 Jul;422(2):128-30. https://doi.org/10.1016/j.neulet.2007.06.001

17. Hasan N, McColgan P, Bentley P, Edwards RJ, Sharma P. Towards the identification of blood biomarkers for acute stroke in humans: a comprehensive systematic review. Br J Clin Pharmacol. 2012 Aug;74(2):230-40. https://doi.org/10.1111/j.1365-2125.2012.04212.x

18. Hsuan Y, Lin C, Chang C, Lin M. Mesenchymal stem cell-based treatments for stroke, neural trauma, and heat stroke. Brain Behav. 2016 Aug;6(10):e00526. https://doi.org/10.1002/brb3.526
19. Bray N, Burrows F, Jones M, Berwick J, Allan S, Schiessi I. Decreased haemodynamic response and decoupling of cortical gammaband activity and tissue oxygen perfusion after striatal interleukin-1 injection. J Neuroinflammation. 2016 Aug;13(1):195. https://doi. org/10.1186/s12974-016-0664-x

20. Bouziana S, Tziomalos K, Goulas A, Hatzitolios Al. The role of adipokines in ischemic stroke risk stratification. Int J Stroke. 2016 Jun;11(4):389-98. https://doi.org/10.1177/1747493016632249

21. Yuan H, Sun L, Li X, Che F, Zhu X, Yang F, et al. Association of adiponectin polymorphism with metabolic syndrome risk and adiponectin level with stroke risk: a meta-analysis. Sci Rep. 2016 Aug;6:31945. https://doi.org/10.1038/srep31945

22. Pietra Pedroso VS, Rachid MA, Teixeira AL. Biomarkers in Post-stroke Depression. Curr Neurovasc Res. 2016;13(2):163-73. https://doi.org/1 $0.2174 / 1567202613666160219120114$

23. Adams HPJR, Bendixen BH, Kappelle LJ, Biller J, Love BB, Gordon DL, et al. Classification of subtype of acute ischemic stroke: definitions for use in a multicenter clinical trial. Stroke. 1993 Jan;24(1):35-41. https://doi.org/10.1161/01.str.24.1.35

24. Pittock SJ, Meldrum D, Hardiman O, Thornton J, Brennan P, Moroney JT. The Oxfordshire Community Stroke Project Classification: correlation with imaging, associated complications, and prediction of outcome in acute ischemic stroke.J Stroke Cerebrovasc Dis. 2003 Jan;12(1):1-7. https://doi.org/10.1053/jscd.2003.7

25. Cincura C, Pontes-Neto Om, Neville Is, Mendes Hf, Menezes Df, Mariano DC, et al. Validation of the National Institutes of Health Stroke Scale, modified Rankin Scale and Barthel Index in Brazil: the role of cultural adaptation and structured interviewing. Cerebrovasc Dis. 2009;27(2):119-22. https://doi.org/10.1159/000177918

26. Brucki SMD, Nitrini R, Caramelli P, Bertolucci PHF,Okamoto IH. Sugestões para o uso do mini-exame do estado mental no Brasil. Arq Neuropsiquiatr. 2003;61(3-B):777-81.http://dx.doi.org/10.1590/S0004-282X2003000500014

27. Rangaraju S, Frankel M, Jovin TG. prognostic value of the 24-hour neurological examination in anterior circulation ischemic stroke: a post hoc analysis of two randomized controlled stroke trials. Interv Neurol. 2016 Mar;4(3-4):120-9. http://dx.doi.org/10.1159/000443801

28. Lambertsen KL, Biber K, Finsen B. Inflammatory cytokines in experimental and human stroke.J Cereb Blood Flow Metab. 2012 Sep;32(9):1677-98. http://dx.doi.org/10.1038/jcbfm.2012.88

29. Kozak HH, Uğuz F, Kilinç I, Uca AU, Serhat Tokgöz O, Akpinar Z, et al. Delirium in patients with acute ischemic stroke admitted to the nonintensive stroke unit: Incidence and association between clinical features and inflammatory markers. Neurol Neurochir Pol. 2017 Jan-Feb;51(1):38-44. http://dx.doi.org/10.1016/j.pjnns.2016.10.004

30. Lasek-Bal A, Jędrzejowska-Szypułka HJ, Różycka J, Bal W, Holecki M, Duława J, et al. Low concentration of BDNF in the acute phase of ischemic stroke as a factor in poor prognosis in terms of functional status of patients. Med Sci Monit. 2015;21:3900-5. http://dx.doi.org/10.12659/MSM.895358

31. Li S, Lu N, Li Z, Jiao B, Wang H, Yang J, Yu T. Adiponectin gene polymorphism and ischemic stroke subtypes in a Chinese population. J Stroke Cerebrovasc Dis. 2017 May;26(5):944-951. http://dx.doi.org/10.1016/j.jstrokecerebrovasdis.2016.10.045

32. Han Q, Shu Z, Liang X, Mi R, Yang L, Li P. Relationship between adiponectin receptor 1 gene polymorphisms and ischemic stroke Int J Clin Exp Med. 2015 Sep;8(9):16719-23

33. Nagasawa H, Yokota C, Toyoda K, Ito A, Minematsu K. High level of plasma adiponectin in acute stroke patients is associated with stroke mortality. J Neurol Sci. 2011 May;304(1-2):102-6. http://dx.doi. org/10.1016/j.jns.2011.02.002

34. Thundyil J, Tang SC, Okun E, Shah K, Karamyan VK, LI Y. Evidence that adiponectin receptor 1 activation exacerbates ischemic neuronal death. Exp Transl Stroke Med. 2010 Aug;2(1):15. http://dx.doi. org/10.1186/2040-7378-2-15 